\title{
Cellularity Measurement
}

National Cancer Institute

\section{Source}

National Cancer Institute. Cellularity Measurement. NCI Thesaurus. Code C111153.

The determination of the amount of degree, quality or condition of cells present in a sample. 